\title{
Climate, tectonics or morphology: what signals can we see in drainage basin sediment yields?
}

\author{
T. J. Coulthard ${ }^{1}$ and M. J. Van de Wiel ${ }^{2}$ \\ ${ }^{1}$ Department of Geography, Environment and Earth Sciences, University of Hull, UK \\ ${ }^{2}$ Department of Geography, University of Western Ontario, London, Ontario, Canada
}

Correspondence to: T. J. Coulthard (t.coulthard@ hull.ac.uk)

Received: 19 May 2013 - Published in Earth Surf. Dynam. Discuss.: 10 June 2013

Revised: 6 September 2013 - Accepted: 16 September 2013 - Published: 7 October 2013

\begin{abstract}
Sediment yields from river basins are typically considered to be controlled by tectonic and climatic drivers. However, climate and tectonics can operate simultaneously and the impact of autogenic processes scrambling or shredding these inputs can make it hard to unpick the role of these drivers from the sedimentary record. Thus an understanding of the relative dominance of climate, tectonics or other processes in the output of sediment from a basin is vital. Here, we use a numerical landscape evolution model (CAESAR) to specifically examine the relative impact of climate change, tectonic uplift (instantaneous and gradual) and basin morphology on sediment yield. Unexpectedly, this shows how the sediment signal from significant rates of uplift ( $10 \mathrm{~m}$ instant or $25 \mathrm{~mm} \mathrm{a}^{-1}$ ) may be lost due to internal storage effects within even a small basin. However, the signal from modest increases in rainfall magnitude (10-20\%) can be seen in increases in sediment yield. In addition, in larger basins, tectonic inputs can be significantly diluted by regular delivery from non-uplifted parts of the basin.
\end{abstract}

\section{Introduction}

Sediment yields from upland basins are driven by tectonics and climate. The magnitude of sediment delivered by this "erosional engine" (Whittaker et al., 2009) is a major control on the size and location of sedimentary units found in depositional basins, and thus creates an opportunity to invert sedimentary records to establish climate and tectonic histories of the source basin.

However, the presence of two major external forcings (climate and tectonics) as well as the internal autogenic processing of these signals (e.g. Jerolmack and Paola, 2010; Van De Wiel and Coulthard, 2010) leads to a plurality of possible interpretations for each sedimentary record. The difficulty of inverting this plurality to establish whether individual or identifiable combinations of forcings can be determined is a fundamental limitation to our present capability to determine past climates and landscape histories from sedimentary records.

At its simplest, the sedimentary system can be split into three components, an upland production "erosional engine"
(Whittaker et al., 2009), transfer of sediment, and deposition in a basin or store. Historically, research has focused on controls in the depositional setting; only more recently have researchers examined how tectonic and climatic changes can alter sediment production. For example, Willgoose et al. (1991), Whipple and Tucker (2002), Tucker and Whipple (2002), and others have demonstrated with numerical models how following uplift there is an increase in basin sediment discharge associated with a "wave" of incision that migrates upwards through a basin. Densmore et al. (2007) showed that for small fans the timing and amplitude of sediment flux to basins is controlled by changes in fault slip rates. Most recently, Armitage et al. (2011) modelled a coupled fan basin system and showed how fault slip rates altered grain size trends - with grain size changing spatially and temporally away from the fan apex. Other researchers have shown how climate changes can also change or increase sediment delivery (Tucker and Slingerland, 1997; Coulthard et al., 2002) through mechanisms such as the extension of the stream network and increased stream powers. Allen and 
Densmore (2000) in their simulations from uplifting catchments suggest that sedimentary records more faithfully represent climate forcings than those from fault variability. Furthermore, physical experiments (Bonnet and Crave, 2003) also showed how erosional landscapes responded sharply to climate change. However, Armitage et al. (2013) found that sediment response was relatively insensitive to short-term climate variability.

One common theme from the above studies and others (Allen, 2008; Humphrey and Heller, 1995; Métivier and Gaudemer, 1999) is that basin response to external forcings is complex and strongly contingent upon the internal basin processing of these forcings. Therefore, there is clearly a need to disentangle the relative impacts of climate, tectonics and autogenics on sediment delivery and how these may manifest themselves in the sedimentary record.

In addition, comparatively little research has examined the transport of sediment from uplands to basin, with many theoretical and modelling studies assuming a direct link between the two. Yet in numerous natural settings there is a considerable length and width of alluvial "conduit" between areas of sediment erosion and deposition and therefore this conduit must play a key role in how signals are transmitted from uplands to basin (Castelltort and Van Den Driessche, 2003). Geomorphological research indicates that this conduit operates in a non-linear way as part of a complex response (e.g. Schumm, 1979) acting to buffer sediment supply signals (Castelltort and Van Den Driessche, 2003; Métivier, 1999), and more recent research has suggested that (geologically) short-term storage in floodplains may "shred" any upstream signals of forcings (Jerolmack and Paola, 2010). Simpson and Castelltort (2012) used a reach-based model to simulate how sediment pulses and water discharge perturbations may be transmitted to depositional settings. Their simulations showed that changes in discharge input and sediment storage (reflected in increased valley floor gradients) led to spikes in sediment associated with increased water inputs. Coulthard et al. (2005) calculated individual sediment budgets for reaches of a medium sized drainage basin from basin simulations carried out over a $9000 \mathrm{yr}$ period. Their research showed that during wetter periods (increased rainfall magnitudes) there was a dramatic increase in sediment yields and this was largely sourced from the lower, valley floor sections of the catchment. In short, wetter climates mined out the valley floor of sediment. Clearly, the behaviour of the conduit between upland erosional areas and the ultimate depositional setting can have a major impact on sediment delivery.

In this paper we apply a numerical landscape evolution model to demonstrate that there are unexpected and major differences between the relative impacts of climate and tectonics on sediment delivery, and illustrate how the shape of the basin and length of conduit imparts an important control on this relationship.

\section{Methods}

\subsection{The CAESAR model}

The simulations were carried out with the CAESAR landscape evolution model (Coulthard et al., 2002; Van de Wiel et al., 2007). The main features of CAESAR are a combined hydrological and hydraulic flow model that operates on a subevent time step, with multi-grain size erosion and deposition as well as slope processes (diffusive creep and landslides). CAESAR was initially developed to examine the relative roles of climate and land cover change on geomorphology and sediment yield and has been applied to a range of real drainage basins with outputs successfully compared to independent field data. These examples include patterns of sedimentation in Alpine environment (Welsh et al., 2009) sediment yields and longer term lowering rates from Northern Australia (Hancock et al., 2010), comparisons to field plot experiments (Coulthard et al., 2012a), predicting patterns of contaminated sediment dispersal (Coulthard and Macklin, 2003) and simulating $9000 \mathrm{yr}$ of drainage basin evolution in the UK (Coulthard and Macklin, 2001).

CAESAR models landscape evolution by routing water over a grid of regular sized cells and changing elevations according to erosion and deposition from fluvial and slope processes. Caesar can be run in two ways: firstly in catchment mode (as used here), where there are no external in-fluxes other than rainfall; and secondly in reach mode, with one or more points at which sediment and water are input into the system. For both modes of operation CAESAR requires several parameters or initial conditions including surface elevation, grain sizes and rainfall (catchment mode) or a flow input (reach mode). In concept, the operation of Caesar is simple, where precipitation falling on the modelled surface drives fluvial and hillslope processes that determine the erosion and deposition for the modelled time step. This changes the topography, which then becomes the starting point for the following time step. Outputs of the model are the elevation changes across the whole modelled topography as well as water discharges and sediment fluxes at the outlet(s) over time. There are four main components in Caesar, a hydrological model, a surface flow model, fluvial erosion and deposition and slope processes.

When running in catchment mode, Caesar uses rainfall precipitation input to generate runoff over the catchment using an adaptation of TOPMODEL (Beven and Kirkby, 1979). TOPMODEL contains a lumped soil moisture store that creates surface runoff when it exceeds a threshold value. The movement of the surface runoff is then simulated using a surface flow model.

CAESAR's flow model uses a "flow-sweeping" algorithm, which calculates a steady-state, uniform flow approximation of the 2-D flow field. In this water discharge is distributed to all cells within a 2-5 cell range in front of a cell according to the differences between the water surface elevation of 
the donor cell and bed elevations of the receiving cells. Flow depths and velocity are calculated from discharges between cells using Manning's equation. These flow depths and velocities are then used to simulate the transport and deposition of sediment. Caesar calculates sediment transport over nine grain size fractions, which can be transported either as bed load or as suspended load, depending on the user specification. Caesar provides two options to calculate sediment transport, using Einstein (1950) or the Wilcock et al. (2003) equations. These equations are used as they calculate sediment transport for each size fraction that allows easy integration with the multiple grain size model components described later. For this study we have chosen to use the Einstein (1950) method where the calculation of sediment transport for each size fraction $i$ involves first determining the balance between the forces moving and restraining a particle:

$\psi=\frac{\left(\rho_{\mathrm{s}}-\rho\right) D_{i}}{\rho \mathrm{d} S}$,

where $\rho_{\mathrm{s}}$ is the sediment density, $\rho$ water density, $D_{i}$ the grain size of the $i$ fraction, $d$ flow depth and $S$ slope. In the above equation the term $\rho \mathrm{d} S$ is replaced by $\tau / g$, where $\tau$ denotes shear stress and $g$ gravitational acceleration. A dimensionless bedload transport rate, $\phi$, can then be estimated from $\psi$ using the relationship established by Einstein (1950):

$\phi=40(1 / \psi)^{3}$.

The value of $\phi$ is then used to rearrange the following equation to estimate $q_{i}$, the rate of sediment transport $\left(\mathrm{m}^{3} \mathrm{~s}^{-1}\right)$ :

$\phi=q_{i} \sqrt{\frac{\rho}{\left(\rho_{\mathrm{s}}-\rho\right) g D_{i}^{3}}}$.

Deposition of sediments differs between bed load and suspended load. At each iteration all transported bed load is deposited in the receiving cells, whereas the deposition of suspended sediments is determined from fall velocities and concentrations for each suspended sediment fraction.

This procedure allows the selective erosion, transport and deposition of the different size fractions resulting in spatially variable sediment size distributions. Since this variability is expressed not only horizontally, but also vertically, CAESAR requires a method of storing sub-surface sediment data. This is enabled with a system of layers comprising an active layer representing the stream bed; multiple buried layers (strata); a base layer; and, if required, an immovable bedrock layer. These strata layers have a fixed thickness and their position is fixed relative to the bedrock layer and up to 20 strata can be stored at any cell on the grid. The active layer represents the river bed and has a variable thickness between $25 \%$ and $150 \%$ of the strata thickness. Erosion removes sediment and causes the active layer thickness to decrease. If the thickness becomes less than a threshold value, then the upper strata layer is incorporated in the active layer to form a new, thicker active layer. Conversely, deposition adds material to the active layer, causing it to grow. If the active layer becomes greater than a set value, a new stratum is created leaving a thinner active layer.

Slope processes are also modelled, with mass movement represented as an instantaneous removal process. When the slope between adjacent cells exceeds a threshold (e.g. 0.5 or 45 degrees) material is moved from the uphill cell to the one below until the angle is lower than the threshold. As a small slide in a cell at the base of a slope may trigger more movement uphill, the model uses an iterative procedure to check the adjacent cells until there is no more movement.

Soil creep is also modelled by CAESAR using the equation below, where $C_{\text {rate }}$ is the user-specified rate of soil creep $\left(\mathrm{m} \mathrm{yr}^{-1}\right), T=$ time (years) and $D x$ grid-cell size. This represents diffusion-like processes whereby sediment flux is linearly proportional to surface slope (Carson and Kirkby, 1972).

Creep $=\frac{\mathrm{SC}_{\text {rate }} T}{D x}$

These mass movement and soil creep formulations allow material from slopes to be fed into the fluvial system as well as the input from landslides (both large scale and small - e.g. bank collapse). After the fluvial erosion/deposition and slope process amounts are calculated, the elevations and grain size properties of the cells are updated simultaneously.

CAESAR required modification to simulate uplift. A simple uplift algorithm was added which raises the elevations of designated cells by a specified amount, $\Delta Z_{\mathrm{u}}$, at a specified time.

\subsection{Model set-up and experimental procedure}

Here, CAESAR was applied to the River Swale located in the North of England (Fig. 1). The section of the Swale modelled in this study lies upstream of Catterick Bridge, consisting of a total basin area of $490 \mathrm{~km}^{2}$. The average elevation within the basin is $357 \mathrm{~m}$, the altitudinal range is $68-712 \mathrm{~m}$ and the average river gradient is 0.0064 . At the headwaters the landscape is characterized by steep valleys and the geology is Carboniferous limestone and millstone grit (Bowes et al., 2003). Further downstream, valleys become less pronounced and the underlying geology becomes Triassic mudstone and sandstone (Bowes et al., 2003).

For the numerical experiments, three different size subbasins of the Swale were used (Fig. 1), herein termed small, medium and large, and located upstream of points S1, S2 and S3, respectively. The initial DEM for the simulations was obtained from the Ordnance Survey "OpenData" DEM library. The climatic inputs into the hydrological component of the model are a $10 \mathrm{yr}$ hourly rainfall data set for the area generated by the UKCP09 weather generator (see Coulthard et al., 2012b), repeated for the length of the simulations. Basin 

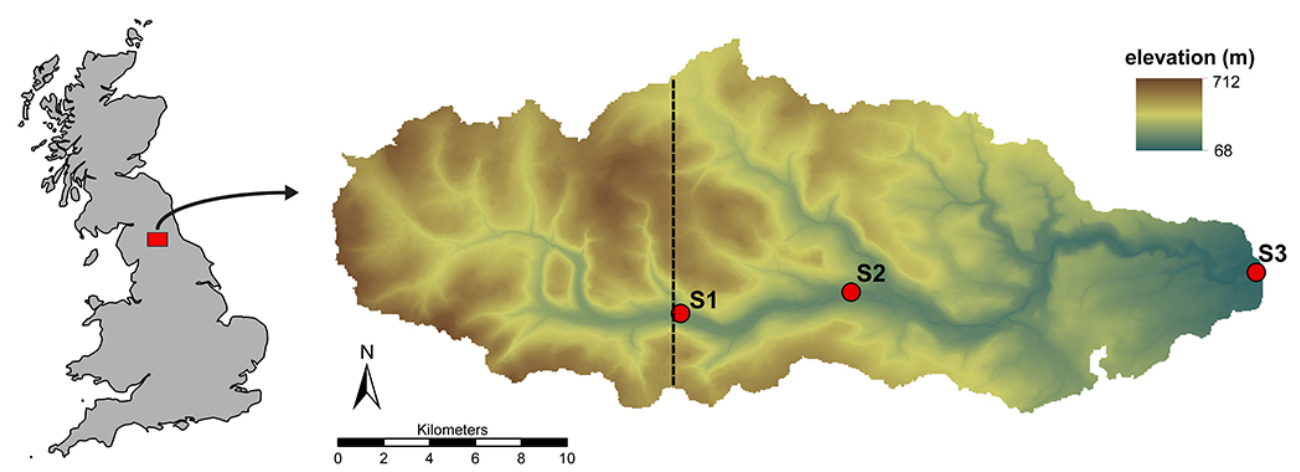

Figure 1. Location map (left) and elevation map (right) of the Swale basin. The area to the west of the fault line (dashed black line) was uplifted in the uplift simulations. Points S1, S2 and S3 indicate three locations where simulated sediment yields were recorded, respectively corresponding to a small, medium and large upstream sub-basin. Point S1 is located immediately downstream of the fault line. Points S2 and $\mathrm{S} 3$ are 10 and $30 \mathrm{~km}$ downstream from the fault line.

Table 1. Sediment yields in uplift scenarios for $100 \mathrm{yr}$ simulations.

\begin{tabular}{lcccccc}
\hline scenario & \multicolumn{2}{c}{ S1 } & \multicolumn{2}{c}{ S2 } & \multicolumn{2}{c}{ S3 } \\
& $\begin{array}{c}\text { cum. yield } \\
\left(10^{6} \mathrm{~m}^{3}\right)\end{array}$ & $\begin{array}{c}\text { rel. change } \\
(\%)\end{array}$ & $\begin{array}{c}\text { cum. yield } \\
\left(10^{6} \mathrm{~m}^{3}\right)\end{array}$ & $\begin{array}{c}\text { rel. change } \\
(\%)\end{array}$ & $\begin{array}{c}\text { cum. yield } \\
\left(10^{6} \mathrm{~m}^{3}\right)\end{array}$ & $\begin{array}{c}\text { rel. change } \\
(\%)\end{array}$ \\
\hline base & 2.18 & 0.0 & 1.63 & 0.0 & 16.16 & 0.0 \\
1 m uplift & 2.23 & 2.5 & 1.65 & 1.2 & 16.24 & 0.5 \\
2.5 m uplift & 2.46 & 13.0 & 1.68 & 3.1 & 16.23 & 0.4 \\
5 m uplift & 2.98 & 36.9 & 1.71 & 4.8 & 16.41 & 1.5 \\
10 m uplift & 3.96 & 81.8 & 2.02 & 24.1 & 16.58 & 2.6 \\
25 m uplift & 6.74 & 209 & 2.67 & 63.7 & 17.78 & 10.0 \\
50 m uplift & 11.82 & 442 & 3.75 & 130 & 19.90 & 23.1 \\
100 m uplift & 21.03 & 865 & 6.12 & 275 & 23.76 & 47.0 \\
250 m uplift & 40.67 & 1767 & 12.78 & 684 & 30.64 & 89.6 \\
\hline
\end{tabular}

hydrology parameters were held constant during all simulated periods. There is no bedrock representation in these simulations, so all incision is into multi-grain sized material.

Nine groups of numerical experiments were conducted (E1 to E9), with each experiment consisting of several simulations in which either climate or uplift were increased over a range of values (Fig. 2). An additional simulation with no change provides a base reference to assess the impact of the changes in external driving conditions. Different experiments were conducted to investigate comparatively short-term impacts, over a period of $100 \mathrm{yr}$ (E1, E2, E6, E7), and longer term impacts, over a period of $900 \mathrm{yr}$ (E3, E4, E5, E7, E8). In these simulations, a year is defined as 365 days, that is, the extra day in leap years is ignored. Although CAESAR runs on sub-daily or sub-hourly time steps, output for the simulations is aggregated to facilitate analysis and interpretation. For the $100 \mathrm{yr}$ simulations, data are aggregated in daily intervals. For the $900 \mathrm{yr}$ simulations a 10 day interval was used. Additional analysis on annual and decadal intervals was done on further aggregation of these daily data.

In all experiments, the changes in rainfall or uplift were initiated at $50 \mathrm{yr}$ into the simulation. For all uplift experi- ments (E1, E3, E5, E6, E8), only the area to the west of point S1 was uplifted (Fig. 2). Uplift is instantaneous in our simulations, with the exception of experiment E5 where a continued gradual uplift is applied every year for the last $850 \mathrm{yr}$ of the simulation. For the climate experiments (E2, E4, E7, E9), the changes in climate were defined as a percentage increase in the base rainfall. This increase is incurred after $50 \mathrm{yr}$ into the simulation, is sustained throughout the remainder of simulations and affects the entire basin (Fig. 2).

\section{Results}

\subsection{Impacts of climate and tectonics on sediment totals}

To investigate the role of tectonics we conducted a series of simulations (experiment E1) on the medium basin by instantaneously uplifting the upper section (i.e. the area west of S1; Figs. 2 and 3) after $50 \mathrm{yr}$ of simulation, and then continuing the simulation for a further $50 \mathrm{yr}$. This was to establish whether there was any rapid/instant response as well as short-term (decadal) changes as the basin adjusts to its new topography. The simulations were repeated several times 
type of change
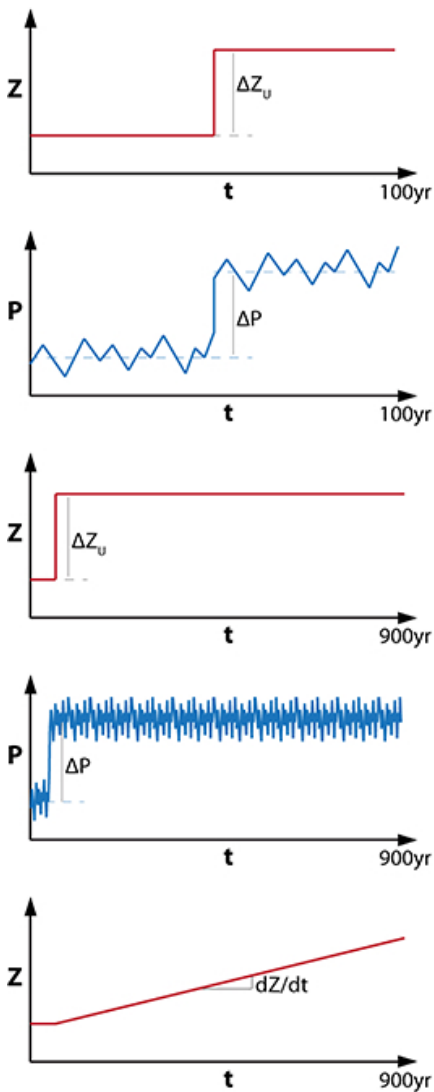

area affected

by change
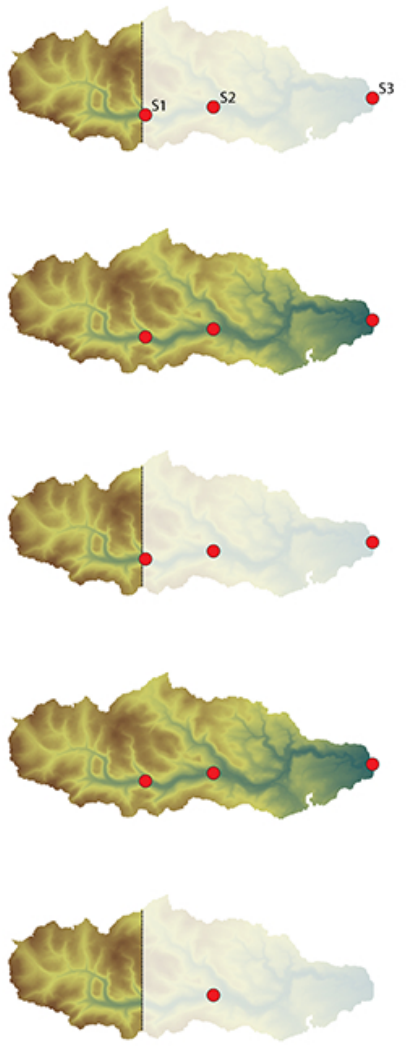

$\Delta \mathrm{P}=10,20,30,40,50 \%$

magnitude of change

$\Delta \mathrm{Z}_{\mathrm{u}}=1,2.5 .5,10,25,50$, $100,250 \mathrm{~m}$

$\Delta P=10,20,30,40,50$,

$60,70,80,90,100 \%$

$\Delta \mathrm{Z}_{\mathrm{u}}=1,2.5,5,10,25,50 \mathrm{~m}$

$\mathrm{dZ} / \mathrm{dt}=5,10,25,50 \mathrm{~mm} / \mathrm{yr}$
E3

E8

E1

E6

E2

E7

E4

E9

Figure 2. Schematic representation of experiment design. Nine numerical experiments were carried out (E1 to E9). Each experiment consists of a group of 4 to 10 simulations, where either rainfall (blue) or uplift (red) was altered after $50 \mathrm{yr}$ into the simulation. In uplift experiments, only the western part of the basin is uplifted. Changes in rainfall affect the entire basin. Red dots on the maps indicate position of output points S1, S2 and S3.

with differing amounts of uplift $\left(\Delta Z_{\mathrm{u}}=1 \mathrm{~m}, 2.5 \mathrm{~m}, 5 \mathrm{~m}, 10 \mathrm{~m}\right.$, $25 \mathrm{~m}, 50 \mathrm{~m}, 100 \mathrm{~m}, 250 \mathrm{~m}$ ). Figure 3 a shows cumulative sediment yields from the basin measured at point $\mathrm{S} 2$ and Table 1 contains cumulative yields and percentage increases in sediment yield. The red lines are from simulations with different instantaneous uplift amounts and generally show an increase in sediment yield following the uplift events. However, uplift of $10 \mathrm{~m}$ or more is required to create a noticeable shift in the cumulative line.

Using the same medium basin but disabling the uplift, we then investigated the role of climate by increasing the magnitude of the rainfall input to the hydrological model after $50 \mathrm{yr}(\mathrm{E} 2)$. The simulations were run with increased rainfall rates $(\Delta P=10$ to $100 \%$, in $10 \%$ intervals). The cumulative sediment yields from these simulations are plotted as blue lines on Fig. 3a. Increasing rainfall magnitude creates a very similar effect as tectonic uplift, though with a small but identifiable instantaneous response (a vertical increase in the cumulative). Overall, comparatively small increases in rainfall magnitude result in relatively large increases in sediment yield (e.g. $20 \%$ increase in rainfall increases sediment yield by $53 \%$; Table 1, Fig. 3a). To achieve a similar increase of sediment yield, a large amount of instantaneous uplift is needed (e.g. $25 \mathrm{~m}$ of uplift results in $64 \%$ increase in yield). In Fig. 4a, we compare the sediment yield totals after $100 \mathrm{yr}$ from all the tectonic and climate simulations that comprised E1 and E2. Relatively modest rises in rainfall magnitudes $(+20 \%,+30 \%)$ result in 50 to $100 \%$ sediment yield increase, which is matched only by large levels of instantaneous uplift (i.e. $25 \mathrm{~m}$ or more). At larger rainfall increases, the difference becomes even starker. For example, approximately $90 \mathrm{~m}$ of uplift is required to achieve the cumulative sediment output from a $50 \%$ increase in rainfall $\left(5.6 \times 10^{6} \mathrm{~m}^{3}\right)$.

These simulations, however, are only over short $100 \mathrm{yr}$ timescales. To investigate longer term trends we extended a 

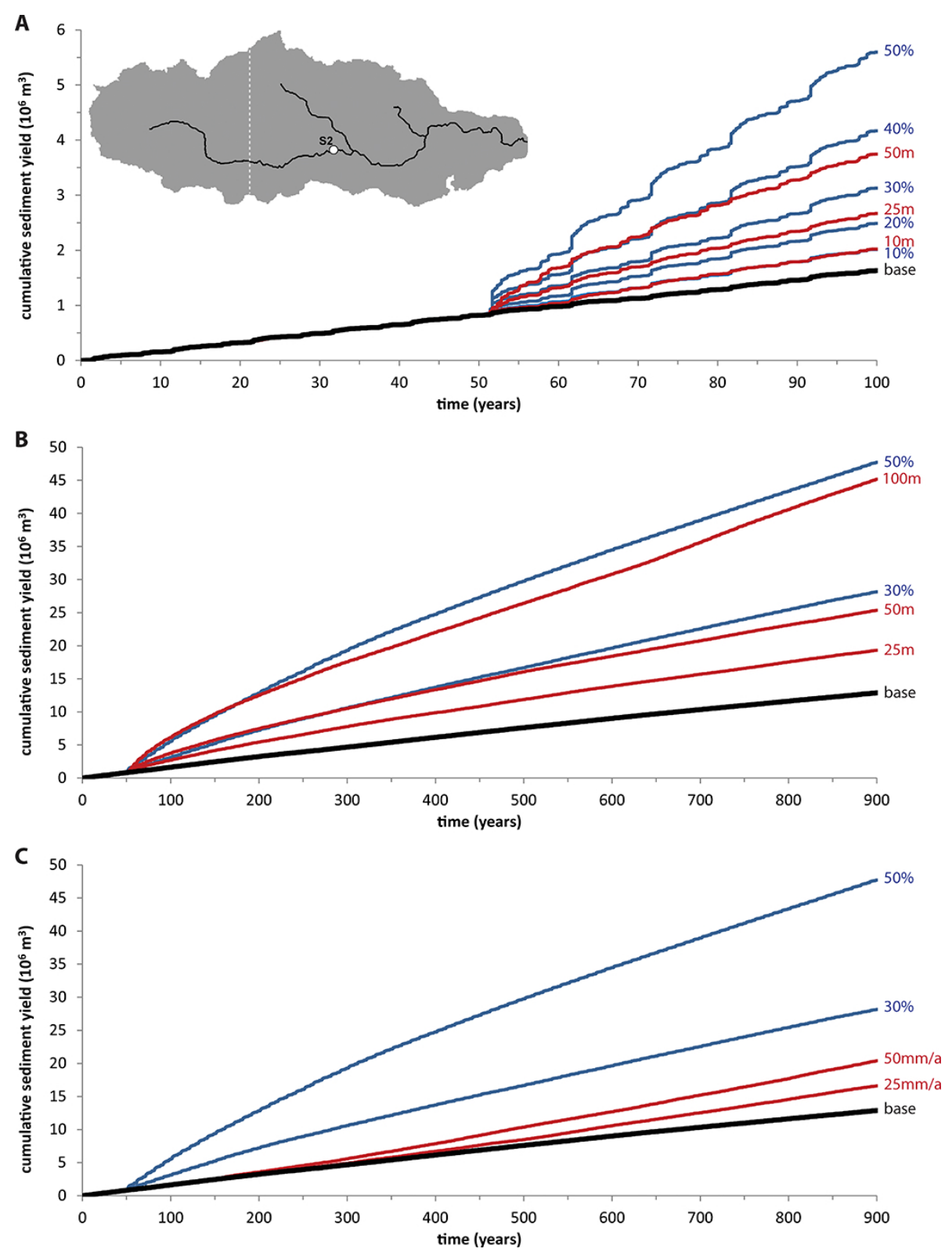

Figure 3. Simulated cumulative sediment yields at point S2 for a range of different scenarios from E1-E5. (A) 100 yr scenarios for rainfall increase and instantaneous uplift (E1, E2). (B) $900 \mathrm{yr}$ scenarios for rainfall increase and instantaneous uplift (E3, E4). (C) 900 yr scenarios for rainfall increase and gradual uplift (E3, E5). The uplift or increase in rainfall occurred at 50 yr. The base scenario (no uplift, no rainfall increase) is shown as a thick black line, rainfall scenarios are shown as blue lines, and tectonic scenarios are shown as red lines. Inset shows location of fault line and measurement point S2.

select number of these runs to continue for $900 \mathrm{yr}$ (E3, E4). Cumulative sediment yields show a very similar response to the shorter term simulations (Fig. 3b). There is a slight decay in the rate of increase in sediment yields after ca. $200 \mathrm{yr}$ from both uplift and climate change - which is in response to locally increased gradients (tectonics) and expanding drainage areas (climate) leading to an initial surge from readily available sediment. Clearly, the trends observed in Fig. 3a are not transient conditions and persist over longer time periods.
We also investigated how gradual uplift $(\mathrm{d} Z / \mathrm{d} t=5,10,25$ and $50 \mathrm{~mm}$ per year) compared to changes in climate (E5). As per previous results we can see that even large rates of gradual uplift are superseded by modest increases in climate (Fig. 3c).

To establish how basin shape and the length of channel between zones of uplift and deposition (the conduit) alter sediment delivery, an additional experiment (E6) was carried out uplifting the same upper section of the basin, but increasing 

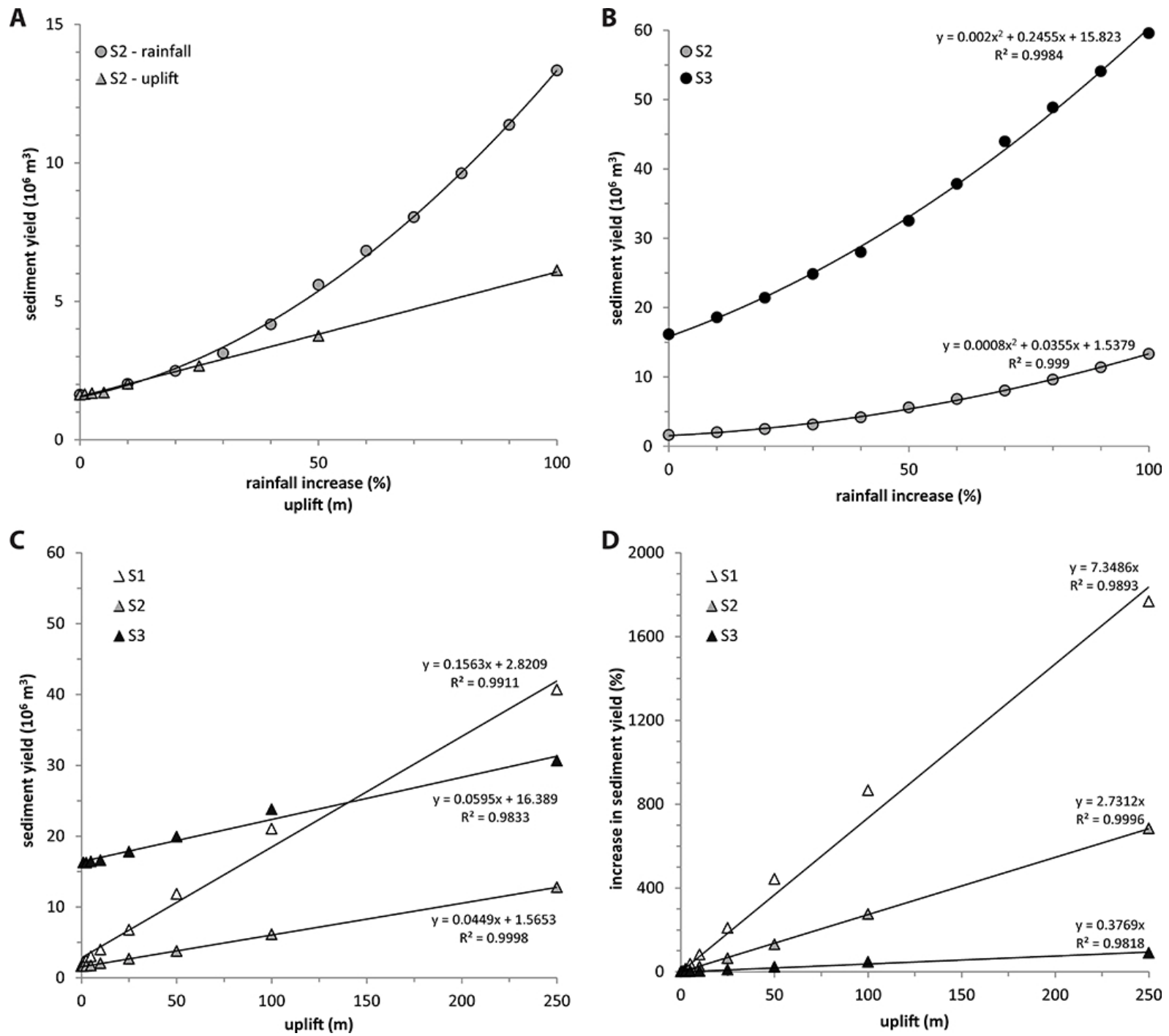

Figure 4. Impact of rainfall increase or tectonic uplift on simulated sediment yields after 100 yr, at point S1, S2 and S3 (see Fig. 1 for locations). (A) Impact of rainfall increase and tectonic uplift on sediment yield after $100 \mathrm{yr}$, at S2. (B) Total sediment yield for rainfall scenarios, at S2 and S3. (C) Total sediment yields for instantaneous uplift scenarios, at S1, S2 and S3. (D) Percentage change in sediment yield, relative to the base scenario, for instantaneous uplift scenarios, at S1, S2, S3.

the distance between uplift and basin outlet. Three size basins were used, with outlets at S1, S2 and S3, respectively $500 \mathrm{~m}$, $10 \mathrm{~km}$ and $30 \mathrm{~km}$ downstream of the uplifted area (Figs. 1,2). As per the previous experiments, uplift was instantaneous and added after $50 \mathrm{yr}$ of simulation. As the temporal response was similar as previous simulations, only the impacts on total sediment yields are shown (Fig. 4c-d). These data demonstrate that the percentage increase in sediment yield due to uplift is highest in the small basin, and progressively smaller in the medium and large basins (Fig. 4d).

In absolute values, sediment yield increases linearly with uplift (Fig. 4c). In the larger basins a noticeable increase in sediment yield only occurs after $25 \mathrm{~m}$ of uplift, and is driven by the relatively substantial changes uplift causes in basin relief (without uplift basin relief is $500 \mathrm{~m}$ ). That aside, however, there are two other processes in operation. Firstly, adding a downstream section of valley floor to accommodate storage of sediment, as is the case in the medium and large basins, removes or "shreds" the part of the signal from the uplift events (Fig. 4c). The physical mechanism for this is evident studying the surface morphology of the simulations, where an alluvial fan forms immediately downstream of the uplift locus (Fig. 5). However, the larger basin does not seem to be more "effective" at shredding this signal than the medium basin, as the curves rise at very similar rates, albeit offset (Fig. 4c). Yet for the larger basin, the percentage change in sediment yield is far less (Fig. 4d). This demonstrates the second process, where the uplift signal is simply 
A
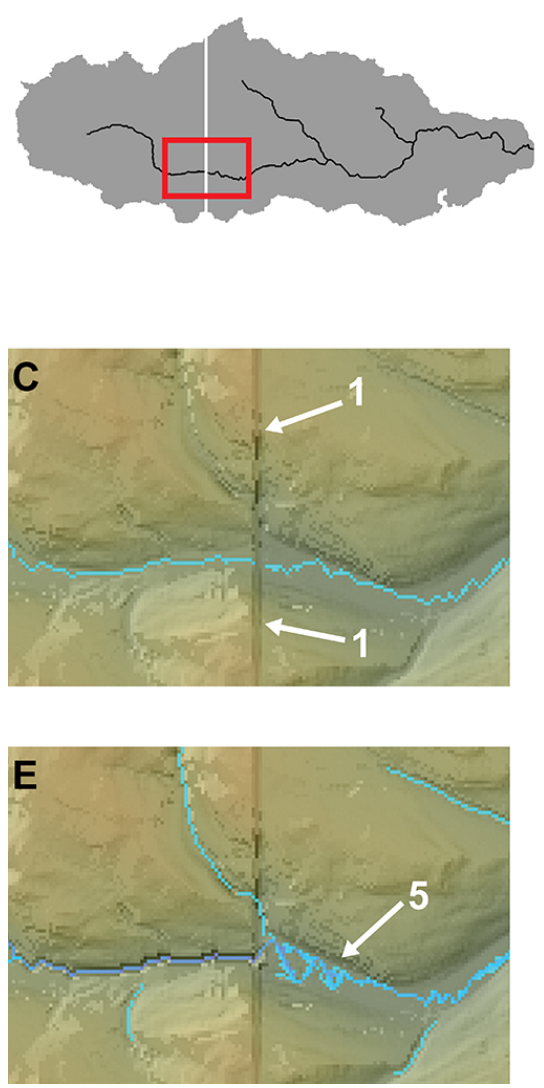
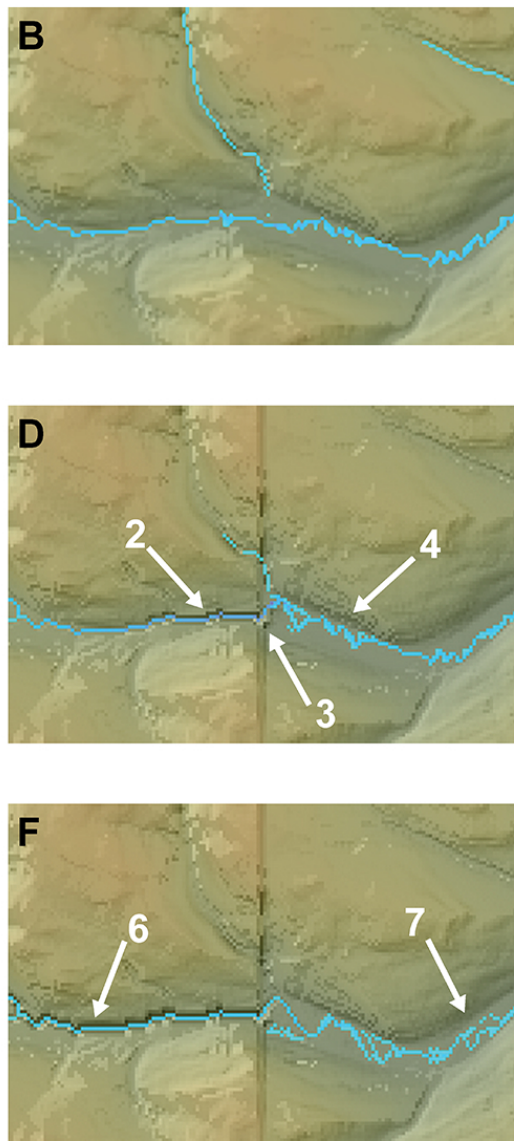

Figure 5. Geomorphic changes occurring after the $50 \mathrm{~m}$ instantaneous uplift scenario. (A) location of fault (solid white line) and area selected for elevation maps (red rectangle). (B-F) Elevation maps of selected area, respectively after 47.9, 50.1, 55.5, 63.5 and 99.2 yr of simulation. Arrows indicate specific features: 1. Escarpment after uplift; 2. Incision of channel upstream of fault line; 3. Formation of small alluvial fan; 4. Braided river pattern downstream of fault line; 5. Expansion of braiding; 6. Continued incision upstream of fault line; 7. Downstream propagation of braided river pattern.

diluted by sediment being added from the non-uplifted parts of the larger basin as the ratio of uplifted area to total basin area decreases.

Next we compared increases in sediment yield from uplift to those from rainfall in different size basins (E7). Unlike the uplift scenarios, where only part of the basin is uplifted, increases in rainfall affect the whole basin (Fig. 2), giving 2 to 3 times larger sediment yields for the larger basin, reflecting its larger area (Fig. 4b).

Figure 5 shows the impacts of $50 \mathrm{~m}$ of uplift on the geomorphology of the simulations around the area uplifted. This shows the before and at four time points, after uplift. Here there are clear changes in the nature of the channel both upstream and downstream. Upstream there is an entrenching of the main stream with a nick point migrating upstream ultimately leaving a river terrace behind. Downstream there is an immediate change in the channel pattern from single thread to braided (indicative of increased sediment yields) and the development of a small alluvial fan.

\subsection{Impacts of climate and tectonics on sediment grain size}

As well as providing information on sediment yields, the multiple grain sizes incorporated within CAESAR allow changes in grain size to be simulated in response to climate and tectonic forcings. Here we focus our discussion on the median grain size, D50, for experiment E6, that is, for the $100 \mathrm{yr}$ simulations with uplift, for the S1, S2 and S3 basins (Fig. 6). These results show the annual mean D50 for all events within a year, and they thus increase and decrease with years that have fewer and greater large flood events. Daily data show similar patterns, but are omitted here as the yearly totals present a clearer picture. Results for D84 show similar trends and are not discussed.

For S1, the $5 \mathrm{~m}$ uplift initially leads to a $20 \mathrm{yr}$ increase in the D50 (Fig. 6a). The initial coarsening agrees with field observations (e.g. Whittaker et al., 2009) associated with higher stream powers due to increased channel gradients (Whittaker et al., 2009). However, this effect begins to attenuate after 

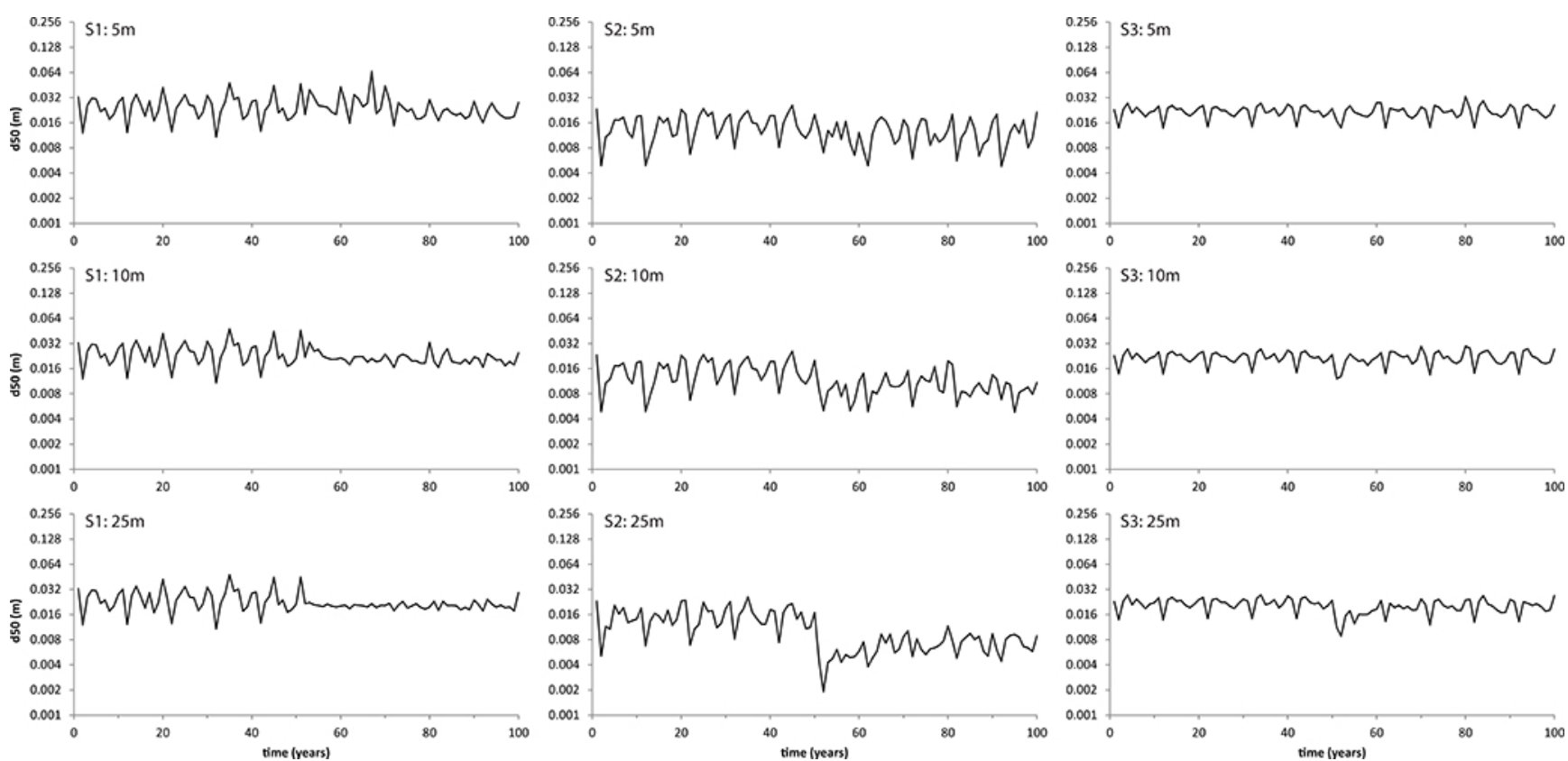

Figure 6. Median annual grain sizes for S1, S2 and S3 for 5, 10 and $25 \mathrm{~m}$ uplift simulations. Values are calculated by summing total daily sediment yields for each of 9 grain sizes output by CAESAR, over a simulated year. This was carried out in preference to calculating daily median grain sizes and then averaging this over a year, which would skew the median grain size by over-weighting the contribution of days with small daily sediment totals.

20 yr with the D50 diminishing to slightly less than that prior to uplift. For $10 \mathrm{~m}$ and $25 \mathrm{~m}$ of uplift there is a very different reaction with both a reduction in D50 and a smoothing of the signal from different annual events. For $10 \mathrm{~m}$ uplift there is a partial recovery in this signal after $30 \mathrm{yr}$ and possibly beginning at $50 \mathrm{yr}$ for $25 \mathrm{~m}$ uplift. The simulated fining associated with uplift is clearly different from expected results of coarsening (Whittaker et al., 2009) and we offer two explanations for this. Firstly, the 10 and $25 \mathrm{~m}$ uplift events we have simulated are very unusual in the field - and therefore it is quite possible we are simulating an effect not observed in the field. Secondly, our model has a high level of connectivity between channel, floodplain and hillslopes. Within our high uplift scenarios significant fluvial incision occurs (see Fig. 5), leading to the immediate introduction of fresh sediment from the collapse of river banks that will be sustained as a wave of incision passes up through the valley floor (as indicated in Fig. 5). The bank and slope material has a relatively higher concentration of fines than sediments in the river bed. In addition, this effect will also translate into tributary streams leading to a sustained input of finer sediment. The reduction in the annual variation in D50 in the $10 \mathrm{~m}$ and $25 \mathrm{~m}$ uplift simulations is a different example of signal shredding. Here the system has been overloaded with finer sediment creating a situation where climatic variations are no longer observed in the D50 (although they are in the total sediment yield).
At S2 all simulations show a fining of the sediment post uplift, with the effect becoming more amplified with greater amounts of uplift (Fig. 6). This shows that some of the finer sediment released from $\mathrm{S} 1$ after uplift is being transported through the reach - though, since the grain size reduction is reduced from $\mathrm{S} 1$ to $\mathrm{S} 2$, a substantial volume and proportionally more of the coarser material is being stored between $\mathrm{S} 1$ and S2. The reduction in interannual variability of the D50 that was observed at $\mathrm{S} 1$ is less noticeable at $\mathrm{S} 2$, although there still is some reduction in the variability as the amount of uplift increases.

For S3 there is little or no variation in D50 pattern in the $5 \mathrm{~m}$ and $10 \mathrm{~m}$ uplift scenarios. Only in the $25 \mathrm{~m}$ uplift scenario is there an observable impact on the D50, namely that the variability decreases. Location S3 is thus sufficiently far downstream of the fault-line for grain size not be affected by the uplift of 5 and $10 \mathrm{~m}$ with only a small impact from the $25 \mathrm{~m}$ uplift. In other words, the valley between S1 and S3 absorbs the effects of the uplift on transported sediment sizes.

Figure 7 describes the impacts of climate on grain size for basins S1, S2 and S3 (experiment E7). Unlike uplift overall there is a far weaker response in the grain size signal to increased wetness. For S1, S2 and S3 there is negligible change in grain size after the $10 \%$ increase in wetness, with any variations indiscernible from variations prior to the increase. However, for larger increases in wetness drops or dips in grain size are amplified. These drops in grain size correspond to wetter years indicating that these correspond to the 

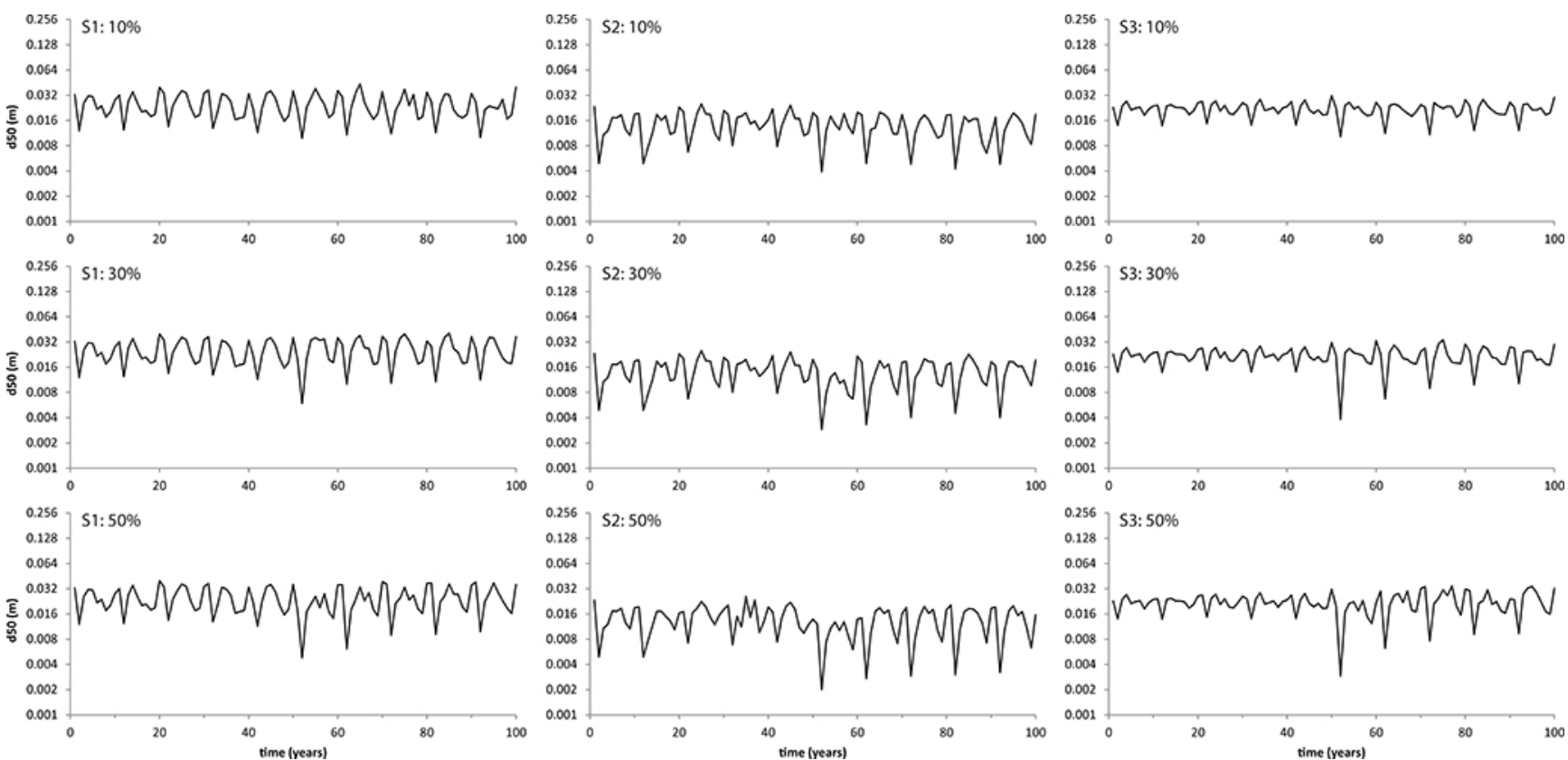

Figure 7. Grain size changes after rainfall changes for S1, 2 and 3 with 10, 30 and $50 \%$ increases in precipitation magnitude after 50 simulated years. Median grain sizes were calculated as per the method outlined in Fig. 6.

increased delivery of fine sediments (from slopes, banks and also incision and expansion of tributaries) during wetter periods.

\subsection{The role of autogenic processes}

Within our results, we believe we can see evidence of autogenic, or internal processes that are creating signals within the basin outputs. In Fig. 8, we have plotted the annual and decadal sediment outputs from the $900 \mathrm{yr}$ uplift simulations (E8), with actual and relative values (relative values are normalised to the mean pre-uplift sediment output).

Signals generated in post uplift sediment curve of S2 and to a lesser extent $\mathrm{S} 3$ are of similar $(10 \mathrm{~m})$ and greater $(5 \mathrm{~m})$ magnitude than peaks immediately following the uplift itself. Therefore, at both annual and decadal timescales the S2 and S3 basins are capable of generating sediment yield peaks equivalent to or greater than those seen immediately after uplift. There is also evidence that uplift changes the nature of sediment outputs from the system. For example, at S2, sediment yield variability increases following uplift (Table 2). This effect is more pronounced and longer lasting as the amount of uplift increases. At S3, only the $25 \mathrm{~m}$ uplift has an impact on the sediment yield variability (Table 2). This is also visible in Fig. 8, where the relative changes (right side graphs) also show there is a greater indication of the uplift signal in S2 than S3 (supporting earlier findings).
Table 2. Variability of relative sediment yield in uplift scenarios for 900 yr simulations.

\begin{tabular}{lllllll}
\hline time period & \multicolumn{3}{c}{$\mathrm{S} 2$} & & \multicolumn{3}{c}{$\mathrm{S} 3$} \\
& $5 \mathrm{~m}$ & $10 \mathrm{~m}$ & $25 \mathrm{~m}$ & $5 \mathrm{~m}$ & $10 \mathrm{~m}$ & $25 \mathrm{~m}$ \\
\hline pre-uplift: 1-50 yr & 0.709 & 0.709 & 0.709 & 0.558 & 0.558 & 0.558 \\
post-uplift: 51-100 yr & 0.775 & 0.952 & 1.626 & 0.497 & 0.520 & 0.600 \\
post-uplift: 451-500 yr & 0.570 & 0.669 & 0.810 & 0.333 & 0.346 & 0.341 \\
post-uplift: 851-900 yr & 0.558 & 0.592 & 0.685 & 0.307 & 0.312 & 0.317 \\
\hline
\end{tabular}

Variability is shown as standard deviations of relative annual sediment yield over the specified time period. Relative annual yields are normalized to the mean yield of the $50 \mathrm{yr}$ pre-uplift period.

\section{Discussion}

These results provide us with considerable insight into how a drainage basin processes different external forcings. In these experiments climate changes clearly generate greater increases in sediment yield than uplift. In this study we have deliberately explored extreme values of climate and uplift, but if we restrict the results to more reasonable values (e.g. instantaneous uplift up to $10 \mathrm{~m}$ and rainfall/climate increases of $30 \%$ ) then in systems where the sedimentary deposits are not proximal to the sediment source, climate changes clearly have a far greater impact on sediment delivery. In our simulations elevated sediment yields from $10 \mathrm{~m}$ of uplift are equivalent to a $10 \%$ increase in rainfall magnitude. Even looking at longer timescales and continual uplift rates of $25 \mathrm{~mm} \mathrm{yr}^{-1}$ equate to a $10 \%$ increase in rainfall.

However, the converse is apparent when examining grain size. Here (especially at S1 and S2) there is a mixed reaction to uplift that generates an increase or decrease in D50 

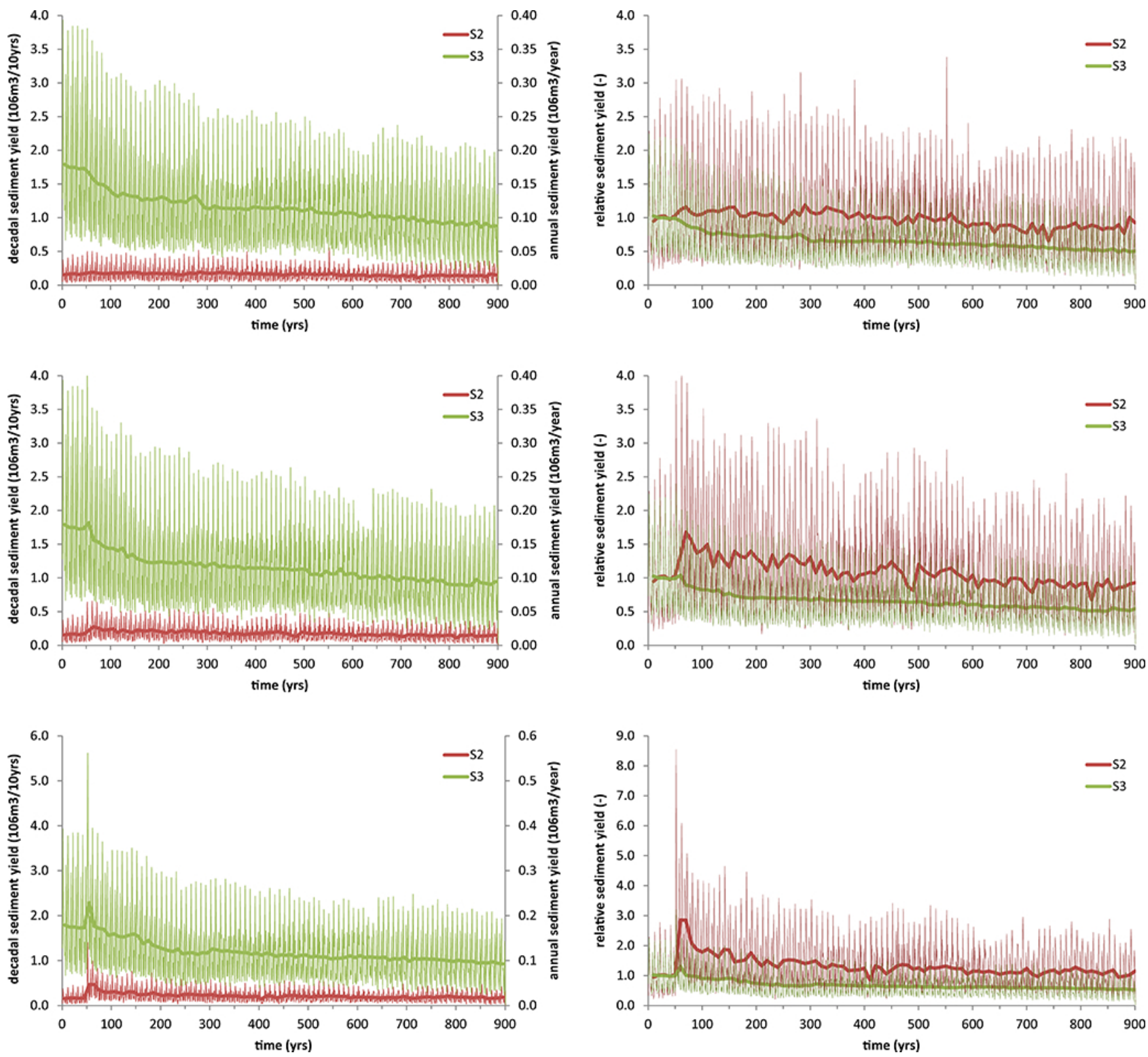

Figure 8. Annual and decadal sediment yields for S2 and S3 over 900 simulated years for 5, 10 and $25 \mathrm{~m}$ of uplift respectively (top to bottom). The left side shows absolute values and the right side relative values (normalised to pre-uplift average).

according to the magnitude of the change (increases associated with smaller amounts of uplift up to $5 \mathrm{~m}$ ). For smaller $(<10 \mathrm{~m})$ amounts of uplift our findings largely agree with those of Armitage et al. (2011) who note the deposition of larger sediment close to the uplift point (equivalent to our S1) with reductions in grain size further away (our S2 and S3). However, for larger uplift values, that is, $10 \mathrm{~m}$ and greater, we observed fining at $\mathrm{S} 1$ instead of coarsening. This would suggest a switch in sediment response above certain levels of uplift. Alterations in climate have a less apparent impact on D50 with the exception of the largest increases in rainfall magnitude (30\% and 50\%) leading to an increased drop in grain size during wetter years.
The role of the sedimentary system "shredding" input signals (Jerolmack and Paola, 2010) is also apparent - with the addition of less than $10 \mathrm{~km}$ of non-uplifted floodplain (the difference between S1 and S2) removing much of the uplift signal from both sediment volume and grain size. In Jerolmack and Paola's paper, they used a physical model of a rice pile - where the storage and (non-linear) release of rice in the pile led to the removal or shredding of any input signal in the output response. We would argue that a floodplain operates in a similar manner to the rice pile by storing and releasing sediment in a non-linear manner. Indeed, other workers have noted non-linear, self organising mechanisms in operation in floodplains with meandering and cut-offs (Hooke, 
2003; Stølum, 1998). Thus, we would argue that for a given flood event the amount of sediment released from the end of a floodplain (bedload not suspended) may or may not bear any relation to the size of the flood event. Interestingly, our simulations show that as basin size increases the impact of "shredding" does not increase, thus indicating that only a short area of accommodation for storage and re-working of sediment is required. Furthermore, as the total area of basin relative to the area uplifted increases, the relative importance of shredding decreases as any signal from the uplift is diluted by sediment from tributaries in non-uplifted parts of the basin.

Our findings support previous work indicating long lag times from tectonic changes that are "buffered" by the fluvial system (Allen, 2008; Métivier and Gaudemer, 1999), in particular within areas of valley floor and floodplain (Castelltort and Van Den Driessche, 2003; Métivier and Gaudemer, 1999; Simpson and Castelltort, 2012) as found in our expanding catchment settings. It is worth noting that increases in sediment delivery are generated by all uplift and climate scenarios - but as catchment area and valley floor length grow, peaks in sediment were smoothed, or lost within the noise of the autogenic signals.

There may be important implications from this research for the interpretation of stratigraphy. Firstly, our results only generate sediment yields at the edge of our simulated drainage basins. We, therefore, do not account for any depositional settings or changes in accommodation space that may occur subsequently downstream. However, we suggest that the thickness of a sedimentary unit found in basins is more likely to represent changes in climate rather than any uplift history, except for where there is a direct and high level of connectivity between source and deposit. Closer to the point of uplift, coarsening in grain size is likely to be indicative of small/moderate uplift, but a fining in grain size indicates either large amounts of tectonic uplift or major increases in rainfall magnitude. In short, changes in the volume of sediment exported from a basin is more contingent on climate than tectonics, yet changes in grain size in this sediment are more likely to represent tectonic changes rather than climate. These findings re-enforce those from Simpson and Castelltort (2012) and of Allen and Densmore (2000) who suggest that discharge/climate variability may be better represented in the sediment signal than tectonic events and comment on the difficulties of inverting the sedimentary record (Simpson and Castelltort, 2012).

These results also indicate that short-term peaks in sediment volume are more likely to be generated by increases in rainfall than uplift events (as per the physical experiments of Bonnet and Crave, 2003). Therefore, marked increases in the thickness of sedimentary units - if representing increases in sediment supply - are more likely to indicate climatic changes rather than tectonic. It is important to note that this "short-term" sediment peak equates to a year or more of increased sediment delivery, rather than that from individual flood events, which may be very difficult to identify (Van de
Wiel and Coulthard, 2010). Furthermore, for moderate levels of uplift, the autogenic factors generate annual and even decadal peaks in sediment of equivalent or greater magnitude than uplift. In other words, the noise generated within the system is greater than the signal from the input.

We are aware that the timescales we have simulated here are considerably shorter than those used in other studies (e.g. Armitage et al., 2011, 2013). However, for sedimentary records over the Holocene and Quaternary scales, we would argue that the changes we are simulating are highly relevant. There are several studies that link increases in Holocene and Quaternary sedimentation rates to shorter term environmental forcings (e.g. Macklin et al., 2006) and even to individual events (e.g. Hinderer and Einsele, 1997; Hinderer, 2001; Larsen et al., 2013). We believe our findings are highly relevant in this context. Conversely, for records spanning tens of millions of years our findings may be less relevant and could just be part of the "noise" of the system. It is also important to note that our simulations are not run to any form of landscape steady state where there is equilibrium between (for example) uplift and erosion, and at these shorter timescales the catchments are always in a state of transience.

An important control on long-term basin development is bedrock - yet in these simulations we have not included its role. Within CAESAR, bedrock can be represented as a layer that is difficult/impossible to erode beneath layers of regolith/alluvium. However, when designing these experiments incorporating this would then introduce another parameter (the depth to bedrock) and we wished to keep the experiments as parsimonious as possible.

It is important to remember that whilst there is an unlimited depth of regolith in our simulations, this is of different grain sizes interacting through an active layer system. Therefore, the model will behave in a supply limited manner. This means that during the model operation the model will preferentially erode the finer fractions from channels and "wear down" any obstructions or high spots in the channel network (termed spinning up or conditioning, Coulthard et al., $2012 b)$. As a result of this conditioning process the basin is left with an armoured channel bed that is relatively stable under the range of events that it formed under (i.e. the topography and rainfall events that formed it). If you perturb the basins driving forces (e.g. via increased precipitation or uplift) there follows an increase in sediment yield as the channel works through the armour layer that it had already developed. Therefore, in many respects, this scenario is identical to a the behaviour of a bedrock channel that experiences uplift or a change in climate, except the reaction speed of the bedrock basin will be far slower. For example, Godart et al. (2013) examine how basin lithology alters the response time of basins to climate changes with different "resonance periods" for harder and softer lithologies. For example a basin with a highly resistant bedrock would not have enough time to respond to short changes in climate - yet softer lithologies could respond (and thus generate 
sediment flux) to such changes (Godart et al., 2013). In addition, bedrock controls will have an increasing importance as the duration of simulations increases - so for the comparatively short times simulated here (100-900 yr) the effects may be less important.

Further complications of including bedrock include the position of channel bedrock sections relative to the point of uplift. For example if the uplift were located where bedrock was on the stream bed, then uplift would have a minimal impact on sediment delivery - as the controlling base level (the bedrock) would rise with the section of the catchment uplifted. However, if at the point of uplift bedrock were $2 \mathrm{~m}$ below the alluvial bed then we would expect a similar response to these simulations - equivalent to $2 \mathrm{~m}$ of uplift. Therefore, the introduction of bedrock below a surface would probably have the impact of reducing any spikes or pulses in sediment yield associated with uplift in effect limiting them to the depth to bedrock. Bedrock at a certain depth could also reduce the sediment output from increases in climate though the reduction would be smaller than for tectonics as climate change would impact across the whole basin.

Vegetation is another factor that could alter the relative result of climate and tectonic change on sediment yield. We did not model vegetation changes in these experiments, but in CAESAR, a simple vegetation model can act to bind the surface together until an erosional threshold is exceeded. This acts to reduce basin sediment output but would have a greater role on reducing the impact of climate change than tectonics - as increased sediment from climate is driven by channel network extension (and incision) into what would be vegetated slopes. Whereas tectonic increases in sediment are driven by local gradient changes that would largely be within non-vegetated (and thus unaffected) channels. The responses of a basin to bedrock and vegetation change are certainly worthy of further research, especially contrasting over the shorter (as per here) and longer timescales.

There are also limitations with the location and model parameterization. Firstly, the Swale is not a tectonically active basin, but was chosen as CAESAR has been extensively evaluated and validated on the Swale over decadal to centennial timescales. For determining how the distance from uplift affected any tectonic or climatic change signal the Swale has a relatively straightforward valley floor and is typical of many upland basins. Importantly, we chose a natural basin over an artificial landscape (e.g. Van De Wiel and Coulthard, 2010) as we wanted to include topographic heterogeneity (tributaries, floodplains, alluvial fans) as well as actual rainfall records and grain sizes. In addition, finding a field site with enough available data (in particular initial conditions e.g. topography) and with a tectonic and climatic history was difficult (as discussed later). We deliberately manipulated uplift rates and climate changes in a rather unrealistic manner, but this is to establish the outer limits of the relationships between climate, uplift and morphology on sediment yield.
Further modes of uplift were tried (fore tilt, back tilt, sideways tilt, gradual and instant) and all gave similar results.

Considering the model and parameterization, compared to alternative landscape evolution models, CAESAR has a different level of process representation. Therefore, some of the phenomena we have simulated here (e.g. different grain size responses to varying uplift) may be missed by different model configurations and parameterizations. For example the recent work by Armitage et al. $(2011,2013)$ is based on a one-dimensional model that whilst accounting for slope processes does not explicitly include them within a twodimensional framework. It is also worth considering that in our study and that of Simpson and Castelltort (2012) hydraulics and flow processes are simulated and both models show a sensitivity of sediment output/throughput to climate. Whereas Armitage et al. (2013) do not simulate the hydraulics and show an insensitivity to climate (essentially impacting water discharge).

These observations raise the question as to what level of process detail, spatial and temporal resolution is required to simulate landscape dynamics. If high levels of detail are required, this may expose a particular problem for long-term landscape modelling, as field data to drive simulations (e.g. initial landscapes, grain sizes, climates) and validate model runs (e.g. stratigraphy, topographic data) are especially hard to come by. In addition, a circularity can develop whereby stratigraphy may be used to validate models, as well as generate driving data - yet could be highly variable and not truly reflect drivers or products of the basins dynamics (e.g. Coulthard et al., 2007; Van De Wiel and Coulthard, 2010).

Finally, assessing the reliability of numerical landscape evolution models is difficult given many of the issues outlined above (initial landscape, grain sizes, past climates etc.). As stated in the model description, CAESAR has successfully simulated landscape evolution in a range of environments (Coulthard and Macklin, 2001, 2003; Coulthard et al., 2012a; Hancock et al., 2011; Welsh et al., 2009), but it is important to question whether the non-linear response of the model is simply a model by-product or a representation of actual basin dynamics? CAESAR has a long history of modelling the non-linear reaction of catchments from 1998 through to 2010 (Coulthard and Van De Wiel, 2007; Coulthard et al., 1998, 2005; Van De Wiel and Coulthard, 2010) and given that similar non-linear dynamics have been well documented in fluvial systems (Cudden and Hoey, 2003; Gomez and Phillips, 1999; Hooke, 2003; Stølum, 1998), we consider the simulation of non-linear sediment dynamics in CAESAR genuine. In addition, CAESAR is certainly not the only model to show non-linear sediment responses. Examples of this include the Lapsus model (Temme and Van De Wiel, 2012), the results of Simpson and Castelltort (2012), and the Zscape model (Allen and Densmore, 2000). The notion that different numerical and physical models, with very different underlying algorithms produce non-linear responses 
indicates that what we simulate is a fundamental process of sediment transport dynamics rather than a model side effect.

\section{Conclusions}

A series of numerical experiments were carried out, in which the impacts of climate change and tectonic uplift on catchment sediment yield was evaluated. Our results indicate that both have an impact on the sediment yield, but the nature of that impact is different. Climate changes are more likely to impact the total volume of the sediment yield. Tectonic uplift, on the other hand is more likely to affect the grain size distribution of the sediment yield. In our simulations, the impacts of tectonic uplift on the volume sediment yield are pronounced immediately downstream of the uplift zone, but considerably less notable the further downstream you check. In effect the tectonic signal is diluted by storage of sediment in the floodplain.

In addition, our results also indicate that autogenic variability of sediment yield, due to temporary storage and release of sediment within the basin, can be of the same magnitude as the spikes in sediment yield associated with the external disturbance, that is, climate change or tectonic uplift.

All of these findings have implications for the reliability and meaning of inverting sedimentary records for determining past environmental and tectonic conditions.

Acknowledgements. M. J. Van de Wiel was supported by a NSERC Discovery Grant. We are very grateful for review comments from Arnaud Temme, Kevin Norton and Greg Hancock. In addition Sebastien Castelltort provided invaluable commentary on certain parts of the manuscript. The CAESAR model and source code is freely available from https://code.google.com/p/caesar-lisflood/.

Edited by: D. Lundbek Egholm

\section{References}

Allen, P. A.: Time scales of tectonic landscapes and their sediment routing systems, Geological Society, London, Special Publications, 296, 7-28, doi:10.1144/SP296.2, 2008.

Allen, P. A. and Densmore, A. L.: Sediment flux from an uplifting fault block, Basin Res., 12, 367-380, doi:10.1046/j.13652117.2000.00135.x, 2000.

Armitage, J. J., Duller, R. A., Whittaker, A. C., and Allen, P. A.: Transformation of tectonic and climatic signals from source to sedimentary archive, Nat. Geosci., 4, 231-235, doi:10.1038/ngeo1087, 2011.

Armitage, J. J., Dunkley Jones, T., Duller, R. A., Whittaker, A. C., and Allen, P. A.: Temporal buffering of climate-driven sediment flux cycles by transient catchment response, Earth Planet. Sc. Lett., 369-370, 200-210, doi:10.1016/j.eps1.2013.03.020, 2013.

Beven, K. J. and Kirkby, M. J.: A physically based, variable contributing area model of basin hydrology / Un modèle à base physique de zone d'appel variable de l'hydrologie du bassin versant, Hydrological Sciences Bulletin, 24, 43-69, doi:10.1080/02626667909491834, 1979.

Bonnet, S. and Crave, A.: Landscape response to climate change: Insights from experimental modeling and implications for tectonic versus climatic uplift of topography, Geology, 31, 123, doi:10.1130/0091-7613(2003)031<0123:LRTCCI >2.0.CO;2, 2003.

Bowes, M. J., House, W. A., and Hodgkinson, R. A.: Phosphorus dynamics along a river continuum, Sci. Total Environ., 313, 199212, doi:10.1016/S0048-9697(03)00260-2, 2003.

Carson, M. A. and Kirkby, M. J.: Hillslope Form and Process, Cambridge University Press, New York, 1972.

Castelltort, S. and Van Den Driessche, J.: How plausible are highfrequency sediment supply-driven cycles in the stratigraphic record?, Sediment. Geol., 157, 3-13, doi:10.1016/S00370738(03)00066-6, 2003.

Coulthard, T. J. and Macklin, M. G.: How sensitive are river systems to climate and land-use changes? A model-based evaluation, J. Quaternary Sci., 16, 347-351, doi:10.1002/jqs.604, 2001.

Coulthard, T. J. and Macklin, M. G.: Modeling longterm contamination in river systems from historical metal mining, Geology, 31, 451, doi:10.1130/00917613(2003)031<0451:MLCIRS>2.0.CO;2, 2003.

Coulthard, T. J. and Van De Wiel, M. J.: Quantifying fluvial non linearity and finding self organized criticality? Insights from simulations of river basin evolution, Geomorphology, 91, 216-235, doi:10.1016/j.geomorph.2007.04.011, 2007.

Coulthard, T. J., Kirkby, M. J., and Macklin, M. G.: Nonlinearity and spatial resolution in a cellular automaton model of a small upland basin, Hydrol. Earth Syst. Sci., 2, 257-264, doi:10.5194/hess-2-257-1998, 1998.

Coulthard, T. J., Macklin, M. G., and Kirkby, M. J.: A cellular model of Holocene upland river basin and alluvial fan evolution, Earth Surf. Proc. Land., 27, 269-288, doi:10.1002/esp.318, 2002.

Coulthard, T. J., Lewin, J., and Macklin, M. G.: Modelling differential catchment response to environmental change, Geomorphology, 69, 222-241, doi:10.1016/j.geomorph.2005.01.008, 2005.

Coulthard, T. J., Hicks, D. M., and Van De Wiel, M. J.: Cellular modelling of river catchments and reaches: Advantages, limitations and prospects, Geomorphology, 90, 192-207, doi:10.1016/j.geomorph.2006.10.030, 2007.

Coulthard, T. J., Hancock, G. R., and Lowry, J. B. C.: Modelling soil erosion with a downscaled landscape evolution model, Earth Surf. Proc. Land., 37, 1046-1055, doi:10.1002/esp.3226, 2012a.

Coulthard, T. J., Ramirez, J., Fowler, H. J., and Glenis, V.: Using the UKCP09 probabilistic scenarios to model the amplified impact of climate change on drainage basin sediment yield, Hydrol. Earth Syst. Sci., 16, 4401-4416, doi:10.5194/hess-16-44012012, 2012 b.

Cudden, J. R. and Hoey, T. B.: The causes of bedload pulses in a gravel channel: the implications of bedload grainsize distributions, Earth Surf. Proc. Land., 28, 1411-1428, doi:10.1002/esp.521, 2003.

Densmore, A. L., Allen, P. A., and Simpson, G.: Development and response of a coupled catchment fan system under changing tectonic and climatic forcing, J. Geophys. Res., 112, F01002, doi:10.1029/2006JF000474, 2007. 
Einstein, H. A.: The Bed-load Function for Sediment Transportation in Open Channel Flows, in: Technical Bulletin No. 1026, USDA Soil Conservation Service, p. 71, US Department of Agriculture, 1950.

Godard, V., Tucker, G. E., Burch Fisher, G., Burbank, D. W., and Bookhagen, B.: Frequency-dependent landscape response to climatic forcing, Geophys. Res. Lett., 40, 859-863, doi:10.1002/grl.50253, 2013.

Gomez, B. and Phillips, J. D.: Deterministic Uncertainty in Bed Load Transport, J. Hydraul. Eng., 125, 305-308, 1999.

Hancock, G., Lowry, J., Coulthard, T., Evans, K. and Moliere, D.: A catchment scale evaluation of the SIBERIA and CAESAR landscape evolution models, Earth Surf. Proc. Land., 35, 863-875, doi:10.1002/esp.1863, 2010.

Hancock, G. R., Coulthard, T. J., Martinez, C., and Kalma, J. D.: An evaluation of landscape evolution models to simulate decadal and centennial scale soil erosion in grassland catchments, J. Hydrol., 398, 171-183, doi:10.1016/j.jhydrol.2010.12.002, 2011.

Hinderer, G. and Einsele, M.: Terrestrial sediment yield and the lifetimes of reservoirs , lakes , and larger basins, Geol. Rundsch., 86, 288-310, 1997.

Hinderer, M.: Dénudation quaternaire récente dans les Alpes, remplissage des vallées et des lacs, charge solide des rivières actuelles, Geodin. Acta, 14, 231-263, doi:10.1016/S09853111(01)01070-1, 2001.

Hooke, J.: River meander behaviour and instability: a framework for analysis, T. I. Brit. Geogr., 28, 238-253, doi:10.1111/14755661.00089, 2003.

Humphrey, N. F. and Heller, P. L.: Natural oscillations in coupled geomorphic systems: An alternative origin for cyclic sedimentation, Geology, 23, 499-502, doi:10.1130/0091-7613(1995)023, 1995.

Jerolmack, D. J. and Paola, C.: Shredding of environmental signals by sediment transport, Geophys. Res. Lett., 37, 1-5, doi:10.1029/2010GL044638, 2010.

Larsen, A., Bork, H.-R., Fuelling, A., Fuchs, M., and Larsen, J. R.: The processes and timing of sediment delivery from headwaters to the trunk stream of a Central European mountain gully catchment, Geomorphology, doi:10.1016/j.geomorph.2013.06.022, in press, 2013.

Macklin, M. G., Benito, G., Gregory, K. J., Johnstone, E., Lewin, J., Michczyńska, D. J., Soja, R., Starkel, L., and Thorndycraft, V. R.: Past hydrological events reflected in the Holocene fluvial record of Europe, Catena, 66, 145-154, doi:10.1016/j.catena.2005.07.015, 2006.

Métivier, F.: Diffusive like buffering and saturation of large rivers, Phys. Rev. E, 60, 5827-5832, doi:10.1103/PhysRevE.60.5827, 1999.
Métivier, F. and Gaudemer, Y.: Stability of output fluxes of large rivers in South and East Asia during the last 2 million years: implications on floodplain processes, Basin Res., 11, 293-303, doi:10.1046/j.1365-2117.1999.00101.x, 1999.

Schumm, S. A.: Geomorphic Thresholds: The Concept and Its Applications, T. I. Brit. Geogr., 4, 485-515, 1979.

Simpson, G. and Castelltort, S.: Model shows that rivers transmit high-frequency climate cycles to the sedimentary record, Geology, 40, 1131-1134, doi:10.1130/G33451.1, 2012.

Stølum, H.: Planform geometry and dynamics of meandering rivers, Geol. Soc. Am. Bull., 11, 1485-1498, 1998.

Temme, A. J. A. M. and Van De Wiel, M. J.: Filtering signals?: complexity experiments with LAPSUS, Geophysical Research Abstracts, EGU General Assembly, 14, 5299, 2012.

Tucker, G. E. and Slingerland, R.: Drainage basin responses to climate change, Water Resour. Res., 33, 2031, doi:10.1029/97WR00409, 1997.

Tucker, G. and Whipple, K.: Topographic outcomes predicted by stream erosion models: Sensitivity analysis and intermodel comparison, J. Geophys. Res., 107, 2179, doi:10.1029/2001JB000162, 2002.

Van De Wiel, M. J. and Coulthard, T. J.: Self-organized criticality in river basins: Challenging sedimentary records of environmental change, Geology, 38, 87-90, doi:10.1130/G30490.1, 2010.

Van de Wiel, M. J., Coulthard, T., Macklin, M., and Lewin, J.: Embedding reach-scale fluvial dynamics within the CAESAR cellular automaton landscape evolution model, Geomorphology, 90, 283-301, doi:10.1016/j.geomorph.2006.10.024, 2007.

Welsh, K. E., Dearing, J. A., Chiverrell, R. C., and Coulthard, T. J.: Testing a cellular modelling approach to simulating lateHolocene sediment and water transfer from catchment to lake in the French Alps since 1826, The Holocene, 19, 785-798, doi:10.1177/0959683609105303, 2009.

Whipple, K. and Tucker, G.: Implications of sediment-fluxdependent river incision models for landscape evolution, J. Geophys. Res., 107, 1-20, 2002.

Whittaker, A. C., Attal, M., and Allen, P. A.: Characterising the origin, nature and fate of sediment exported from catchments perturbed by active tectonics, Basin Res., 22, 809-828, doi:10.1111/j.1365-2117.2009.00447.x, 2009.

Wilcock, P. R., Crowe, J. C., and Wilcock, P. Crowe, J.: Surface-based transport model for mixed-size sediment, J. Hydraul. Eng., 129, 120-128, doi:10.1061/(ASCE)07339429(2003)129:2(120), 2003.

Willgoose, G., Bras, R. L., and Rodriguez-Iturbe, I.: A coupled channel network growth and hillslope evolution model 1. Theory, Water Resour. Res., 27, 1671-1684, doi:10.1029/91WR00935, 1991. 